\title{
(PENINGKATAN KETERAMPILAN MENULIS TEKS BERITA MENGGUNAKAN METODE MIND MAPPING DAN MEDIA VIDEO)
}

\author{
Indri Suwarti1), Etin Pujihastuti ${ }^{2)}$ dan Bivit Anggoro Prasetyo Nugroho ${ }^{3)}$ \\ 1)Unsoed \\ E-mail: indrisuwarti02.is@gmail.com \\ 2) Unsoed \\ E-mail: etinpujihastuti8@gmail.com \\ 3)Unsoed \\ E-mail: bivit.nugroho@unsoed.ac.id
}

\begin{abstract}
Info Artikel
Sejarah Artikel:

Diterima April

2020

Disetujui Mei

2020

Dipublikasikan

Juni 2020

Abstrak

Penelitian ini didasarkan pada masalah rendahnya keterampilan menulis teks berita siswa kelas VIII B SMP Negeri 1 Karanglewas. Rendahnya keterampilan menulis teks berita dikarenakan siswa tidak tertarik untuk mengikuti pembelajaran bahasa Indonesia. Ketidaktertarikan siswa terhadap pembelajaran disebabkan oleh komponen pendukung dalam proses pembelajaran yang kurang maksimal yaitu guru kurang memanfaatkan metode dan media pembelajaran. Berawal dari masalah tersebut, maka peneliti menawarkan suatu alternatif metode pembelajaran yang dapat digunakan dalam pembelajaran menulis teks berita, yaitu metode mind mapping. Desain penelitian yang digunakan dalam penelitian ini adalah desain penelitian tindakan kelas (PTK) dengan menerapkan tiga siklus. Teknik pengumpulan data yang digunakan adalah teknik tes dan nontes. Teknik analisis data dalam penelitian ini menggunakan teknik kuantitatif dan kualitatif. Teknik kuantitatif digunakan untuk mengetahui hasil tes menulis teks berita siswa, sedangkan teknik kualitatif digunakan untuk mengetahui hasil nontes berupa perubahan perilaku belajar siswa. Berdasarkan hasil tes, keterampilan menulis teks berita siswa mengalami peningkatan yang dapat dilihat dari nilai rata-rata yang diperoleh pada setiap siklusnya. Pada prasiklus, nilai rata-rata yang diperoleh sebesar 61, siklus I nilai rata-rata diperoleh sebesar 71,34 , dan siklus II nilai rata-rata yang diperoleh mencapai 82,94. Selain itu, berdasarkan hasil nontes juga menunjukkan adanya perubahan perilaku belajar siswa ke arah yang lebih baik.
\end{abstract}

Kata Kunci: mind mapping, media video, keterampilan menulis teks 


\section{berita}

\section{Abstract}

This study is based on the low competence in writing news texts of students of VIII B SMP Negeri 1 Karanglewas. This is because the students are not interested in joining Bahasa Indonesia class. The students' lack of interest is due to the not-maximum supporting components, such as the teachers who do not make use of learning method and media. From that situation, the researcher offers a learning method to use in writing news text as an alternative solution, which is mind mapping. The design used in the study is Classroom Action Research (CAR) or PTK using 3 (three) cycles. The data collecting techniques used are test and non-test. Data analysis techniques use quantitative and qualitative techniques. The quantitative is used to find out the result of the students' writing test in writing news texts, while the qualitative one is to find out the nontest result which is the change in the students' learning behavior. According to the test result, the students' writing skill in writing news texts increases based on the increasing average scores in each cycle. In the pre-cycle, the average score is 61, cycle I records 71.34 and cycle II records 82.94. Furthermore, the non-test results show improvement in the students' learning behavior.

Keyword: mind mapping, video as media, writing skill news article

\section{PENDAHULUAN}

Menulis merupakan salah satu keterampilan berbahasa yang harus dikuasai oleh siswa, mata pelajaran Bahasa Indonesia menjadi salah satu mata pelajaran yang berkaitan erat dengan keterampilan menulis. Salah satu kompetensi dasar yang terdapat pada kurikulum 2013 kelas VIII adalah KD 4.2 menyajikan data informasi dalam bentuk berita secara lisan dan tulis dengan memperhatikan struktur, kebahasaan, atau aspek lisan (lafal, intonasi, mimik, kinesik). Namun, pada kenyataannya keterampilan siswa dalam menulis teks berita masih sangat rendah. Hal tersebut dibuktikan berdasarkan hasil tes awal (prasiklus) menulis teks berita, nilai rata-rata yang diperoleh adalah 61, sedangkan KKM yang telah ditetapkan adalah 72 . Selain itu, dari total 32 siswa hanya 6 siswa yang tuntas KKM dan 26 siswa lainnya memperoleh nilai di bawah KKM. Rendahnya keterampilan menulis teks berita 
dikarenakan siswa tidak tertarik untuk mengikuti pembelajaran. Ketidaktertarikan siswa terhadap pembelajaran disebabkan oleh komponen pendukung dalam proses pembelajaran yang kurang maksimal yaitu guru kurang memanfaatkan metode dan media pembelajaran. Peran guru dalam hal ini sangat diperlukan untuk memotivasi siswa agar lebih antusias dalam mengikuti pembelajaran menulis teks berita. Guru dituntut menggunakan model, metode, maupun media yang kreatif agar siswa lebih tertarik untuk mengikuti pembelajaran. Berawal dari masalah di atas, maka peneliti menawarkan suatu alternatif metode pembelajaran yang dapat digunakan dalam pembelajaran menulis teks berita, yaitu metode mind mapping. Buzan (2012:4) mengungkapkan bahwa mind mapping merupakan cara mencatat yang kreatif, efektif, dan secara harfiah akan memetakan pikiran. Pemilihan metode mind mapping dalam penelitian ini bertujuan untuk mempermudah siswa menulis unsur-unsur berita serta teks berita. Selain metode pembelajaran, peneliti juga menawarkan suatu media yaitu media video. Menurut Arsyad (2017:50) video merupakan media yang dapat menggambarkan suatu objek yang bergerak bersama-sama dengan suara alamiah atau suara yang sesuai. Media video ini bertujuan untuk merangsang dan mempermudah siswa menentukan unsur-unsur berita sekaligus menuangkan ide menjadi teks berita. Berdasarkan permasalahan yang telah dipaparkan di atas, tujuan penelitian ini sebagai berikut 1) Mendeskripsikan peningkatan keterampilan menulis teks berita setelah mengikuti pembelajaran menggunakan metode mind mapping dengan bantuan media video pada siswa kelas VIII B SMP Negeri 1 Karanglewas, 2) Mendeskripsikan perubahan perilaku belajar siswa kelas VIII B SMP Negeri 1 Karanglewas setelah mengikuti pembelajaran menulis teks berita menggunakan metode mind mapping dengan bantuan media video.

Kajian yang digunakan sebagai kerangka teoretis pada penelitian ini adalah menulis, berita, penggunaan bahasa Indonesia, metode mind mapping, dan media video. Menurut Dalman (2018:3) menulis merupakan suatu kegiatan komunikasi berupa penyampaian pesan secara tertulis kepada pihak lain dengan menggunakan bahasa tulis sebagai alat atau medianya. Berita adalah laporan tercepat mengenai fakta atau ide terbaru yang benar, menarik dan atau penting bagi sebagian besar khalayak, melalui media berkala seperti surat kabar, radio, televisi, atau media online lainnya (Sumadiria 2016:65). Menurut Kemendikbud (2016:1-57), bahasa Indonesia mengalami perkembangan yang sangat pesat sebagai dampak kemajuan ilmu pengetahuan, teknologi, dan seni. Penggunaannya pun semakin luas dalam beragam ranah baik lisan maupun tulis. Salah satu syarat bahasa tulis yang baik adalah dengan memerhatikan penggunaan ejaan bahasa Indonesia (EBI). Daryanto (2017:182) mengartikan mind mapping sebagai proses memetakan pikiran untuk menghubungkan konsep-konsep permasalahan tertentu dari cabang-cabang sel saraf 
membentuk korelasi konsep menuju suatu pemahaman dan hasilnya dituangkan langsung di atas kertas dengan animasi yang disukai dan gampang dimengerti oleh pembuatnya sehingga tulisan yang dihasilkan merupakan gambaran langsung dari cara kerja koneksi-koneksi di dalam otak. Sementara itu, Arsyad (2017:50) menyatakan bahwa video merupakan media yang dapat menggambarkan suatu objek yang bergerak bersama-sama dengan suara alamiah atau suara yang sesuai. Adapun penelitian yang relevan dengan penelitian ini yaitu penelitian yang dilakukan oleh Supriyanto (2016) dalam skripsinya yang berjudul "Peningkatan Kemampuan Menulis Naskah Drama dengan Menggunakan Metode Peta Pikiran pada Siswa Kelas XI Teknik Komputer Jaringan 1 SMK Negeri 1 Purbalingga Tahun Ajaran 2015-2016". Penelitian yang relevan juga pernah dilakukan oleh Ameri (2018), mahasiswi Universitas Jenderal Soedirman dalam skripsinya yang berjudul "Peningkatan Keterampilan Menulis Teks Berita dengan Metode Peta Pikiran Berbantuan Media Gambar pada Siswa Kelas VIII B SMP Negeri 6 Purwokerto". Penelitian yang sejenis juga dilakukan oleh Nazarrotin, dkk (2018), mahasiswa Universitas Bengkulu dalam jurnal JuRiDikDas yang berjudul "Pengaruh Metode Mind Mapping Terhadap Kemampuan Menulis Karangan Narasi".

\section{METODE PENELITIAN}

Penelitian tindakan kelas ini dilaksanakan di kelas VIII B SMP Negeri 1 Karanglewas yang beralamat di Desa Tamansari, Karanglewas, Banyumas. Waktu penelitian mulai 22 Agustus sampai 11 September 2019. Penelitian ini menggunakan desain penelitian tindakan kelas (PTK) yang terdiri atas empat tahap yaitu, perencanaan, tindakan, pengamatan, dan refleksi. Keempat tahapan ini diterapkan dalam penelitian yang meliputi prasiklus, siklus I, dan siklus II. Subjek penelitian yaitu siswa kelas VIII B SMP Negeri 1 Karanglewas. Jumlah siswa di kelas VIII B adalah 32 siswa yang terdiri atas 18 siswa laki-laki dan 14 siswa perempuan. Selain itu, terdapat pula pihak-pihak yang membantu penelitian ini yaitu teman sejawat dan guru Bahasa Indonesia SMP Negeri 1 Karanglewas yakni Ibu Novi.

Instrumen penelitian yang digunakan pada penelitian ini yaitu instrumen tes dan nontes. Instrumen tes digunakan sebagai alat untuk mengukur kemampuan dasar dan tingkat keberhasilan siswa dalam keterampilan menulis teks berita, sedangkan instrumen nontes digunakan untuk mengetahui aktivitas siswa, kesan siswa, pesan siswa terhadap pembelajaran dan potret kegiatan pembelajaran. Instrumen nontes yang digunakan dalam penelitian ini adalah pedoman wawancara, pedoman observasi, angket, dan dokumentasi.

Teknik pengumpulan data yang digunakan dalam penelitian ini sama halnya dengan instrumen penelitian, yaitu menggunakan teknik tes dan nontes. Teknik tes digunakan 
untuk mengetahui nilai yang diperoleh siswa. Teknik nontes berupa wawancara digunakan untuk mengetahui informasi mengenai pembelajaran menulis teks berita sekaligus respon siswa terhadap pembelajaran menulis teks berita menggunakan metode mind mapping dengan bantuan media video. Wawancara dilakukan kepada perwakilan siswa yang memperoleh nilai tinggi, sedang, dan rendah. Selain itu, wawancara juga dilakukan kepada guru Bahasa Indonesia. Observasi digunakan untuk mengetahui perilaku siswa saat proses pembelajaran berlangsung. Observasi dilakukan dengan cara mengamati sikap dan tingkah laku siswa selama mengikuti pembelajaran menulis teks berita dengan cara mencatat pada lembar pengamatan. Angket bertujuan untuk mendapatkan informasi mengenai tanggapan siswa dalam mengikuti pembelajaran menulis teks berita. Angket dilakukan dengan cara siswa mengisi lembar angket di akhir pembelajaran setiap siklus. Dokumentasi digunakan sebagai bukti visual proses pembelajaran untuk mengetahui perubahan perilaku siswa. Observasi dilakukan dengan cara merekam serta memotret proses pembelajaran yang sedang berlangsung.

Teknik analisis data yang digunakan dalam penelitian ini yaitu teknik kuntitatif dan kualitatif. Teknik kuantitatif digunakan untuk menganalisis data berupa angka yang diperoleh dari hasil tes menulis teks berita pada prasiklus, siklus I, dan siklus II. Teknik kualitatif dilakukan untuk menganalisis data kualitatif yang diperoleh melalui wawancara, observasi, angket, dan dokumentasi.

\section{HASIL DAN PEMBAHASAN}

Hasil penelitian tindakan kelas ini diperoleh dari pelaksanaan tes awal (prasiklus), siklus I, dan siklus II. Hasil penelitian terdiri atas hasil tes dan nontes. Hasil tes diperoleh berdasarkan penilaian keterampilan menulis teks berita setelah mengikuti pembelajaran menuis teks berita menggunakan metode mind mapping dengan bantuan media video dan hasil nontes diperoleh berdasarkan hasil wawancara, observasi, angket, serta dokumentasi pada saat proses pembelajaran berlangsung. Proses pembelajaran menulis teks berita menggunakan metode mind mapping dengan bantuan media video yang dilaksanakan pada siklus I dan siklus II terangkum dalam empat kegiatan inti. Kegiatan inti tersebut meliputi: (1) proses pemberian stimulus berupa video, (2) proses ketika siswa membuat mind mapping, (3) proses ketika siswa membuat teks berita berdasarkan hasil mind mapping, dan (4) pembacaan teks berita yang telah dibuat. Aspek yang dinilai dalam pembelajaran ini meliputi: (1) aspek kelengkapan isi teks berita, (2) aspek sistematika penulisan teks berita, (3) aspek penggunaan kaidah kebahasaan teks berita, dan (4) aspek ketepatan penggunaan ejaan. Berdasarkan hasil tes prasiklus dan siklus I menunjukkan adanya peningkatan keterampilan menulis teks berita. Peningkatan ini dipengaruhi oleh penggunaan 
metode mind mapping dengan bantuan media video. Prasiklus merupakan kegiatan pembelajaran tanpa metode yang digunakan sebagai tes awal keterampilan menulis teks berita. Data yang diperoleh pada prasiklus yaitu, aspek kelengkapan isi teks berita sebesar 78,85\%, aspek sistematika penulisan teks berita sebesar $40,88 \%$, aspek penggunaan kaidah kebahasaan teks berita sebesar 51,13\%, aspek ketepatan penggunaan ejaan sebesar $73,28 \%$. Hasil tes prasiklus secara keseluruhan memperoleh nilai rata-rata 60 dan masih dalam kategori kurang. Nilai keseluruhan pada prasiklus belum memenuhi Kriteria Ketuntasan Minimal (KKM) yang telah ditentukan yakni 72. Selain itu, siswa yang memenuhi kriteria KKM hanya 6 siswa, 26 siswa lainnya masih di bawah KKM. Pada pembelajaran prasiklus siswa masih menunjukkan perilaku yang negatif yaitu siswa terlihat kurang tertarik dan antusias dalam mengikuti pembelajaran, siswa cenderung kurang memperhatikan penjelasan guru, bergurau dengan teman, dan pasif saat mengikuti pembelajaran.

Untuk mengatasi rendahnya keterampilan menulis teks berita siswa maka dilakukan tindakan siklus I. Siklus I merupakan awal diterapkannya metode mind mapping dengan bantuan media video pada pembelajaran. Pada pembelajaran siklus I terjadi peningkatan keterampilan menulis teks berita dan perubahan perilaku siswa ke arah yang lebih baik. Data yang diperoleh dari pembelajaran siklus I menunjukkan bahwa hasil tiap-tiap aspek mengalami peningkatan yaitu, aspek kelengkapan isi teks berita menjadi $81,88 \%$, aspek sistematika penulisan teks berita menjadi $72,38 \%$, aspek penggunaan kaidah kebahasaan teks berita menjadi 57,38\%, aspek ketepatan penggunaan ejaan menjadi $73,75 \%$. Nilai rata-rata siswa yang diperoleh pada siklus I sebesar 71,34 tetapi masih dalam kategori kurang. Pada siklus I, siswa yang memenuhi KKM sejumlah 22 siswa dan 10 siswa lainnya belum memenuhi. Berdasarkan hasil nontes pada siklus I juga terdapat perubahan perilaku siswa ke arah yang lebih baik diantaranya, siswa terlihat lebih antusias ketika mengikuti pembelajaran, lebih aktif, dan lebih sungguhsungguh dalam membuat teks berita. Ternyata tidak semua siswa menunjukkan sikap positif, masih terdapat beberapa siswa yang menunjukkan sperilaku negatif seperti bergurau, pasif, dan tidak bersungguh-sungguh dalam menulis teks berita. Dengan demikian, perlu dilakukan tindakan siklus II untuk memperbaiki kekurangan-kekurangan yang ada pada siklus I agar hasil menulis teks berita siswa yang diperoleh lebih maksimal. Tindakan siklus II merupakan kelanjutan dari tindakan siklus I. Tindakan tersebut dilaksanakan karena pada siklus I nilai yang diperoleh belum memenuhi target kriteria ketuntasan minimal yaitu 72 atau berkategori cukup. Selain itu, pada tindakan siklus I masih terdapat siswa yang menunjukkan perilaku kurang baik saat pembelajaran. Oleh karena itu, tindakan siklus II dilakukan untuk memperbaiki tindakan siklus I. Pembelajaran siklus II menunjukkan adanya peningkatan keterampilan menulis teks berita dan perubahan perilaku yang cukup signifikan. Data yang diperoleh dari pembelajaran siklus II 
menunjukkan bahwa hasil tiap-tiap aspek mengalami peningkatan yaitu, aspek kelengkapan isi teks berita menjadi 87,50\%, aspek sistematika penulisan teks berita menjadi 90,63\%, aspek penggunaan kaidah kebahasaan teks berita menjadi 80,60\%, dan aspek ketepatan penggunaan ejaan menjadi $74,06 \%$. Data peningkatan nilai ratarata per aspek di atas dapat dapat digambarkan pada tabel di bawah.

TABEL 1. Perbandingan Nilai Tiap Aspek Menulis Teks Berita

\begin{tabular}{|c|l|c|c|c|c|c|}
\hline \multirow{2}{*}{ No } & \multicolumn{1}{|c|}{$\begin{array}{c}\text { Aspek } \\
\text { Penilaian }\end{array}$} & $\begin{array}{c}\text { Pra- } \\
\text { siklus }\end{array}$ & $\begin{array}{c}\text { Siklus } \\
\text { I }\end{array}$ & $\begin{array}{c}\text { Peningkatan } \\
\text { Prasiklus ke } \\
\text { Siklus I }\end{array}$ & $\begin{array}{c}\text { Siklus } \\
\text { II }\end{array}$ & $\begin{array}{c}\text { Peningkatan } \\
\text { Siklus I ke } \\
\text { Siklus II }\end{array}$ \\
\cline { 2 - 7 } 1 & $\begin{array}{l}\text { Aspek } \\
\text { Kelengkapan } \\
\text { Isi Teks Berita }\end{array}$ & 78,85 & 81,88 & 3,30 & 87,50 & 5,62 \\
\hline 2 & $\begin{array}{l}\text { Aspek } \\
\text { Sistematika } \\
\text { Penulisan Teks } \\
\text { Berita }\end{array}$ & 40,88 & 72,38 & 31,50 & 90,63 & 18,25 \\
\hline 3 & $\begin{array}{l}\text { Aspek } \\
\text { Penggunaan } \\
\text { Kaidah } \\
\text { Kebahasaan } \\
\text { Teks Berita }\end{array}$ & 51,13 & 57,38 & 6,25 & 80,50 & 23,12 \\
\hline 4 & $\begin{array}{l}\text { Aspek } \\
\text { Ketepatan } \\
\text { Penggunaan } \\
\text { Ejaan }\end{array}$ & 73,28 & 73,75 & 0,47 & 74,06 & 0,31 \\
\hline
\end{tabular}

Data tabel 1 di atas menunjukkan bahwa nilai rata-rata tiap aspek pada penilaian menulis teks berita mengalami peningkatan dari prasiklus hingga siklus II. Aspek penilaian yang pertama yaitu kelengkapan isi teks berita. Aspek kelengkapan isi teks berita untuk tahap prasiklus nilai rata-ratanya adalah 78,85. Kemudian, untuk siklus I nilai rata-ratanya 81,88 dan mengalami peningkatan sebesar 3,30, sedangkan pada siklus II nilai rata-ratanya mencapai 87,50 dan mengalami peningkatan sebesar 5,62. Hal ini menunjukkan bahwa dengan adanya penerapan metode mind mapping dengan bantuan media video memudahkan siswa untuk menulis teks berita secara lengkap sesuai dengan unur-unsurnya. Mind mapping sangat membantu siswa untuk menuangkan unsur-unsur teks berita.

Aspek penilaian yang kedua yaitu sistematika penulisan teks berita. Pada aspek ini, nilai rata-rata yang diperoleh pada tahap prasiklus adalah 40,88. Kemudian, pada siklus I nilai rata-rata meningkat menjadi 72,38 mengalami peningkatan sebesar 
31,50 dan pada siklus II nilai rata-rata yang diperoleh mencapai 90,63 dengan peningkatan sebesar 18,25. Hasil tersebut menunjukkan bahwa siswa sudah dapat meulis teks berita sesuai dengan struktur yang tepat dan lengkap.

Aspek yang ketiga yaitu penggunaan kaidah kebahasaan teks berita. Pada aspek ini, nilai rata-rata yang diperoleh pada tahap prasiklus adalah 51,13 , sedangkan nilai ratarata pada siklus I mencapai 57,38 dan mengalami peningkatan sebesar 6,25. Pada siklus II nilai rata-rata siswa mencapai 80,5 dan mengalami peningkatan sebesar 23,12 dari siklus I ke siklus II. Hasil tersebut menunjukkan bahwa siswa sudah dapat menulis teks berita sesuai dengan kaidah kebahasaan yang tepat.

Aspek penilaian terakhir dalam menulis teks berita adalah ketepatan penggunaan ejaan bahasa Indonesia. Nilai rata-rata yang diperoleh pada prasiklus adalah 73,28, sedangkan pada siklus I adalah 73,75. Kemudian, pada siklus II nilai rata-rata yang diperoleh adalah 74,06. Pada prasiklus ke siklus I mengalami peningkatan sebesar 0,47 dan peningkatan dari siklus I ke siklus II sebesar 0,31. Peningkatan nilai rata-rata pada aspek ini kurang signifikan karena siswa masih kurang memperhatikan ejaan yang digunakan dalam teks berita masing-masing. Siswa masih sering salah dalam penggunaan huruf kapital dan lupa untuk mengakhiri pernyataan dengan menggunakan tanda baca titik.

Selain terjadi peningkatan pada tiap aspek juga terjadi peningkatan keseluruhan nilai rata-rata siswa dari prasiklus, siklus I, hingg siklus II. Peningkatan tersebut dapat dilihat pada tabel 2 di bawah ini.

TABEL 2. Perbandingan Hasil Tes Menulis Teks Berita

\begin{tabular}{|c|c|c|c|c|c|c|c|c|c|}
\hline \multirow[t]{2}{*}{ No } & \multirow[t]{2}{*}{ Kategori } & \multicolumn{2}{|c|}{ Prasiklus } & \multicolumn{2}{|c|}{ Siklus I } & \multirow[t]{2}{*}{ Peningkatan } & \multicolumn{2}{|c|}{ Siklus II } & \multirow[t]{2}{*}{ Peningkatan } \\
\hline & & $\begin{array}{c}\text { Jumlah } \\
\text { Nilai }\end{array}$ & $\begin{array}{c}\text { Nilai } \\
\text { Rata- } \\
\text { rata }\end{array}$ & $\begin{array}{c}\text { Jumlah } \\
\text { Nilai }\end{array}$ & $\begin{array}{c}\text { Nilai } \\
\text { Rata- } \\
\text { rata }\end{array}$ & & $\begin{array}{c}\text { Jumlah } \\
\text { Nilai }\end{array}$ & $\begin{array}{c}\text { Nilai } \\
\text { Rata- } \\
\text { rata }\end{array}$ & \\
\hline 1 & $\begin{array}{l}\text { Baik } \\
\text { sekali }\end{array}$ & 0 & \multirow{5}{*}{$\begin{array}{l}\frac{1952}{32} \\
=61\end{array}$} & 0 & $\frac{2283}{32}$ & \multirow[t]{6}{*}{10,34} & 372 & $\frac{2654}{32}$ & \multirow[t]{6}{*}{11,6} \\
\hline 2 & Baik & 171 & & 427 & $=$ & & 1294 & $=$ & \\
\hline 3 & Cukup & 311 & & 1288 & \multirow[t]{3}{*}{71,34} & & 857 & \multirow[t]{3}{*}{82,94} & \\
\hline 4 & Kurang & 1470 & & 568 & & & 131 & & \\
\hline \multicolumn{2}{|c|}{ Jumlah } & 1952 & & 2283 & & & 2654 & & \\
\hline \multicolumn{2}{|c|}{ Kategori } & \multicolumn{2}{|c|}{ Kurang } & \multicolumn{2}{|c|}{ Kurang } & & \multicolumn{2}{|c|}{ Baik } & \\
\hline
\end{tabular}


Berdasarkan hasil tes keterampilan menulis teks berita siswa pada prasiklus, siklus I, dan siklus II maka dapat digambarkan sebuah diagram untuk mengetahui peningkatan yang terjadi pada setiap siklusnya. Berikut merupakan penjelasannya.

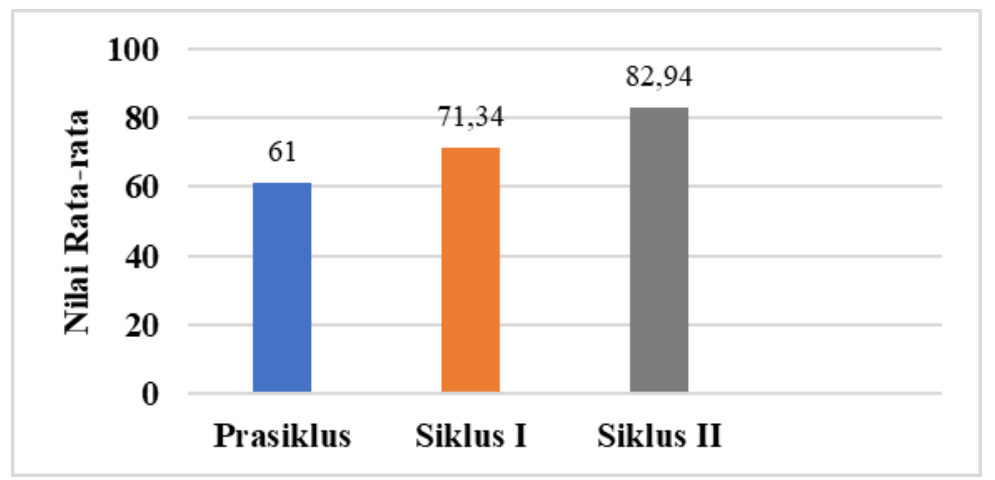

Gambar 1. Diagram Peningkatan Keterampilan Menulis Teks Berita Siswa

Berdasarkan gambar 1 di atas dapat dilihat bahwa nilai rata-rata menulis teks berita pada prasiklus, siklus I, dan siklus II mengalami peningkatan. Pada prasiklus nilai rata-rata kelas yang diperoleh yaitu 61 masuk dalam kategori kurang. Pada siklus I menunjukkan nilai rata-rata 71,34 dengan dan masih dalam kategori kurang. Mengalami peningkatan nilai rata-rata sebesar 10,34 dari hasil prasiklus ke siklus I. Kemudian, pada siklus II nilai rata-rata yang diperoleh yaitu 82,94 dengan dan sudah masuk kategori baik. Mengalami peningkatan nilai rata-rata sebesar 11,6 dari siklus I ke siklus II.

Setelah penelitian dilakukan, selain terjadi peningkatan pada hasil tes keterampilan menulis teks berita juga terjadi perubahan perilaku siswa ke arah yang lebih baik pada saat proses pembelajaran berlangsung. Perubahan tersebut dapat dilihat berdasarkan hasil nontes dari prasiklus sampai dengan siklus II yang meliputi observasi, angket, wawancara, dan dokumentasi. Hasil nontes menunjukkan bahwa terjadi perubahan perilaku siswa ke arah yang lebih baik di antaranya, siswa lebih tertarik dan antusias untuk mengikuti pembelajaran, siswa lebih aktif, siswa lebih memperhatikan penjelasan dari guru, dan siswa lebih sungguh-sungguh dalam menulis teks berita.

\section{PENUTUP}

\section{Simpulan}

Berdasarkan hasil penelitian dan pembahasan di atas maka dapat disimpulkan bahwa penggunaan metode mind mapping dengan bantuan media video dapat meningkatkan keterampilan menulis teks berita pada siswa kelas VIII B SMP Negeri 1 Karanglewas. 
1. Hasil penelitian meunjukkan bahwa setelah mengikuti pembelajaran menulis teks berita menggunakan metode mind mapping dengan bantuan media video, nilai keterampilan menulis teks berita siswa mengalami peningkatan. Hasil nilai ratarata siswa yang diperoleh pada prasiklus sebesar 61 dan masuk dalam kategori kurang dan persentase siswa yang tuntas belajar hanya 18,75\%. Kemudian, pada siklus I nilai rata-rata siswa yang diperoleh mencapai 71,34 dan masih dalam kategori kurang dengan ketuntasan sebesar 68,75\%. Dari hasil prasiklus ke siklus I ini mengalami peningkatan nilai rata-rata sebesar 10,34. Pada siklus II, nilai ratarata siswa sudah mencapai 82,94 dan masuk dalam kategori baik dengan persentase ketuntasan belajar siswa mencapai 93,75\%. Dari hasil siklus I ke siklus II mengalami peningkatan nilai rata-rata siswa sebesar 11,28. Persentase ketuntasan belajar siswa yang dicapai mengalami peningkatan yaitu dari prasiklus ke siklus I sebesar 50\% dan dari siklus I ke siklus II sebesar 25\%.

2. Hasil penelitian menunjukkan adanya perubahan perilaku belajar siswa ke arah yang lebih baik yaitu siswa menjadi lebih tertarik dan antusias mengikuti pembelajaran, lebih aktif, dan lebih bersungguh-sungguh dalam menulis teks berita.

\section{Saran}

Berdasarkan pembahasan hasil penelitian dan simpulan di atas, saran yang dapat peneliti sampaikan adalah

1. Guru hendaknya memanfaatkan metode mind mapping dengan bantuan media video sebagai alternatif metode dalam pembelajaran menulis teks berita karena metode mind mapping dengan bantuan media video ini dapat memudahkan siswa untuk menemukan unsur-unsur berita, menentukan struktur berita, menemukan kaidah kebahasaan berita, dan mengembangkannya menjadi teks berita.

2. Bagi peneliti yang akan melakukan penelitian mengenai keterampilan menulis teks berita hendaknya melakukan penelitian dengan menggunakan metode pembelajaran yang lebih kreatif dan variatif sehingga siswa lebih tertarik mengikuti pembelajaran.

\section{DAFTAR PUSTAKA}

Ameri, Greta Olimpia. 2018. "Peningkatan Keterampilan Menulis Teks Berita Dengan Metode Peta Pikiran Berbantuan Media Gambar Pada Siswa Kelas VIII B SMP Negeri 6 Purwokerto". Skripsi. Fakultas Ilmu Budaya Universitas Jenderal Soedriman.

Arifin, Zainal. 2017. Evaluasi Pembelajaran. Bandung: PT Remaja Rosdakarya. 
Arikunto, Suharsimi, dkk. 2016. Penelitian Tindakan Kelas. Jakarta: Bumi Aksara

Arsyad, Azhar. 2017. Media Pembelajaran. Jakarta: PT RajaGrafindo Persada.

Barus, Sedia Willing. 2010. Jurnalistik Petunjuk Teknis Menulis Berita. Jakarta: Penerbit Erlangga.

Buzan, Tony. 2012. Buku Pintar Mind Mapp. Jakarta: PT Gramedia Pustaka Utama.

Dalman. 2018. Keterampilan Menulis. Depok: Rajawali Pers.

Daryanto dan Syaiful Karim. 2017. Pembelajaran Abad 21. Yogyakarta: Gava Media.

Kartikawati, Rizka. 2019. "Peningkatan Keterampilan Menulis Surat Pribadi dengan Model Mind Mapping pada Siswa Kelas VII F SMP Negeri 7 Purwokerto". Skripsi. Fakultas Ilmu Budaya Universitas Jenderal Soedirman.

Kementerian Pendidikan dan Kebudayaan. 2017. Panduan Penilaian Oleh Pendidik dan Satuan Pendidikan Untuk Sekolah Menengah Pertama. Jakarta: Kementerian Pendidikan dan Kebudayaan

. 2016. Pedoman Umum Ejaan Bahasa Indonesia. Jakarta: Kementerian Pendidikan dan Kebudayaan.

Kosasih, E. 2017. Bahasa Indonesia SMP/MTs Kelas VIII. Jakarta: Kementerian Pendidikan dan Kebudayaan.

Nazzarotin, Ilmi, dkk. 2018. "Pengaruh Metode Mind Mapping Terhadap Kemampuan Menulis Karangan Narasi". Juridikdas. Vol. 1. No. 1. Hal. 15-20. https://ejournal.unib.ac.id/index.php/jurdikdasunib/. Diakses 26 Juni 2019. Pukul 18.58 WIB.

Ngalimun. 2017. Strategi Pendidikan. Yogyakarta: Penerbit Parama Ilmu.

Nurgiyantoro, Burhan. 2016. Penilaian Pembelajaran Bahasa Berbasis Kompetensi. Yogyakarta: BPEE-Yogyakarta.

Romli, Asep Syamsul M. 2014. Jurnalistik Praktis untuk Pemula. Bandung: PT Remaja Rosdakarya.

Sadiman, Arief S, dkk. 2014. Media Pendidikan. Jakarta: PT Rajagrafindo Persada.

Sudijono, Anas. 2009. Pengantar Statistik Pendidikan. Jakarta: PT Rajagrafindo Persada.

Sugiyono. 2018. Metode Penelitian Kuantitatif, Kualitatif, dan R\&D. Bandung: Alfaberta. 
Prawara: Jurnal Pendidikan Bahasa dan Sastra Indonesia e-ISSN: 12345678

Universitas Jenderal Soedirman

Vol. x, No. x, Bulan 20xx

Sujiranto. 2018. Model Pembelajaran Guru Abad 21. Bandung: Mujahid Press.

Sukmadinata, Nana Syaodih. 2015. Metode Penelitian Pendidikan. Bandung: PT Remaja Rosdakarya.

Sumadiria. A.S Haris. 2016. Jurnalistik Indonesia Menulis Berita dan Feature. Bandung: Simbiosa Rekatama Media. 